\title{
PENGARUH BUDAYA ORGANISASI DAN KOMUNIKASI INTERNAL TERHADAP KINERJA YANG DIMEDIASI OLEH KEPUASAN KERJA PEGAWAI PADA DINAS KESEHATAN KABUPATEN TABANAN
}

\author{
Made Dyah Ayu Pranita ${ }^{(1)}$ \\ Ida Ayu Made Sasmita Dewi ${ }^{(2)}$ \\ ${ }^{(1,2)}$ Fakultas Ekonomi Universitas Hindu Indonesia, Bali, Indonesia \\ Email:dyahayupranita@gmail.com
}

\begin{abstract}
ABSTRAK
Penelitian ini bertujuan untuk mengetahui pengaruh budaya organisasi, komunikasi internal terhadap kepuasan kerja pegawai, pengaruh budaya organisasi, komunikasi internal terhadap kinerja, pengaruh budaya organisasi terhadap kinerja melalui kepuasan kerja pegawai sebagai variabel mediasi, dan pengaruh komunikasi internal terhadap kinerja melalui kepuasan kerja pegawai sebagai variabel mediasi pada Dinas Kesehatan Kabupaten Tabanan di Tabanan.

Penelitian menggunakan kuesioner skala Likert, jumlah sampel 88 responden dengan metode sensus. Teknik analisa data dengan path analysis, yang didahului dengan pengujian uji validitas dan reliabilitas. Uji hipotesis menggunakan uji Sobel. Hasil penelitian menunjukkan budaya organisasi berpengaruh positif dan signifikan terhadap kepuasan kerja pegawai dengan koefisien jalur sebesar 0,431. Komunikasi internal berpengaruh positif dan signifikan terhadap kepuasan kerja pegawai dengan koefisien jalur sebesar 0,608. Budaya organisasi berpengaruh positif dan signifikan terhadap kinerja dengan koefisien jalur sebesar 0,368. Komunikasi internal berpengaruh positif dan signifikan terhadap kinerja dengan koefisien jalur sebesar 0,519. Kepuasan kerja pegawai berpengaruh positif dan signifikan terhadap kinerja dengan koefisien jalur sebesar 0,148. Budaya organisasi berpengaruh positif dan signifikan terhadap kinerja melalui kepuasan kerja pegawai sebagai variabel mediasi. Komunikasi internal berpengaruh positif dan signifikan terhadap kinerja melalui kepuasan kerja pegawai sebagai variabel mediasi, maka dapat disarankan bahwa Instansi Dinas Kesehatan Kabupaten Tabanan harus memperhatikan interaksi bagi setiap pegawai, serta memperbaiki sistem pemberian tunjangan uang makan bagi pegawai, agar pegawai termotivasi untuk lebih meningkatkan kepuasan kerja, yang dapat mempengaruhi kinerja dimasa mendatang.
\end{abstract}

Kata kunci: budaya organisasi, komunikasi internal, kepuasan kerja, kinerja. 


\section{PENDAHULUAN}

Penyediaan sumber daya manusia yang memadai dan merata di setiap fasilitas pelayanan kesehatan di seluruh wilyah Indonesia seperti yang tercantum dalam keputusan Menteri Kesehatan Nomor 81/Menkes/SK/I/2004, tentang Pedoman Penyusunan Perencanaan Sumber Daya Manusia Kesehatan di Tingkat Propinsi, Kabupaten/Kota dan Rumah Sakit perlu disesuaikan dengan kebutuhan dan perkembangan hukum.

Sebagai salah satu elemen utama yang menempati posisi sangat strategis dalam organisasi, SDM membutuhkan budaya organisasi merupakan filosofi dasar organisasi yang memuat keyakinan, norma-norma, dan nilai-nilai bersama yang menjadi karekteristik inti tentang bagaimana melakukan sesuatu dalam organisasi, menurut Tintami et al dalam Wibowo (2011:19). Budaya organisasi tidak akan berjalan dengan baik apabila komunikasi yang terjadi pada organisasi mengalami masalah. Untuk mencegah hal tersebut, diperlukan komunikasi dalam organisasi.

Kinerja adalah hasil kerja secara kualitas dan kuantitas yang dicapai oleh seorang pegawai dalam melaksanakan tugasnya sesuai dengan tanggung jawab yang diberikan kepadanya, menurut Mangkunegara (2009:67). Kinerja tidak akan berjalan baik, apabila tidak di dorong dengan adanya kepuasan kerja pada saat bekerja.

Suatu instansi didirikan karena mempunyai tujuan yang ingin dicapai. Seperti halnya yang terjadi pada Dinas Kesehatan (Dinkes), merupakan salah satu Satuan Kerja Pemerintah Daerah (SKPD) di lingkungan pemerintah Kota Tabanan yang bertanggung jawab dalam bidang pembangunan kesehatan. 
Tolak ukur kinerja pada Dinas Kesehatan Kabupaten Tabanan dapat dilihat dari tingkat disiplin pegawai saat memulai hingga mengakhiri kerja perharinya. Selain itu, tingkat absensi pegawai juga mempengaruhi kinerja. Berikut ini merupakan tabel data kehadiran pegawai Dinkes Tabanan.

Tabel 1.1

Data Kehadiran Pegawai Pada Dinas Kesehatan Kabupaten Tabanan Tahun 2016

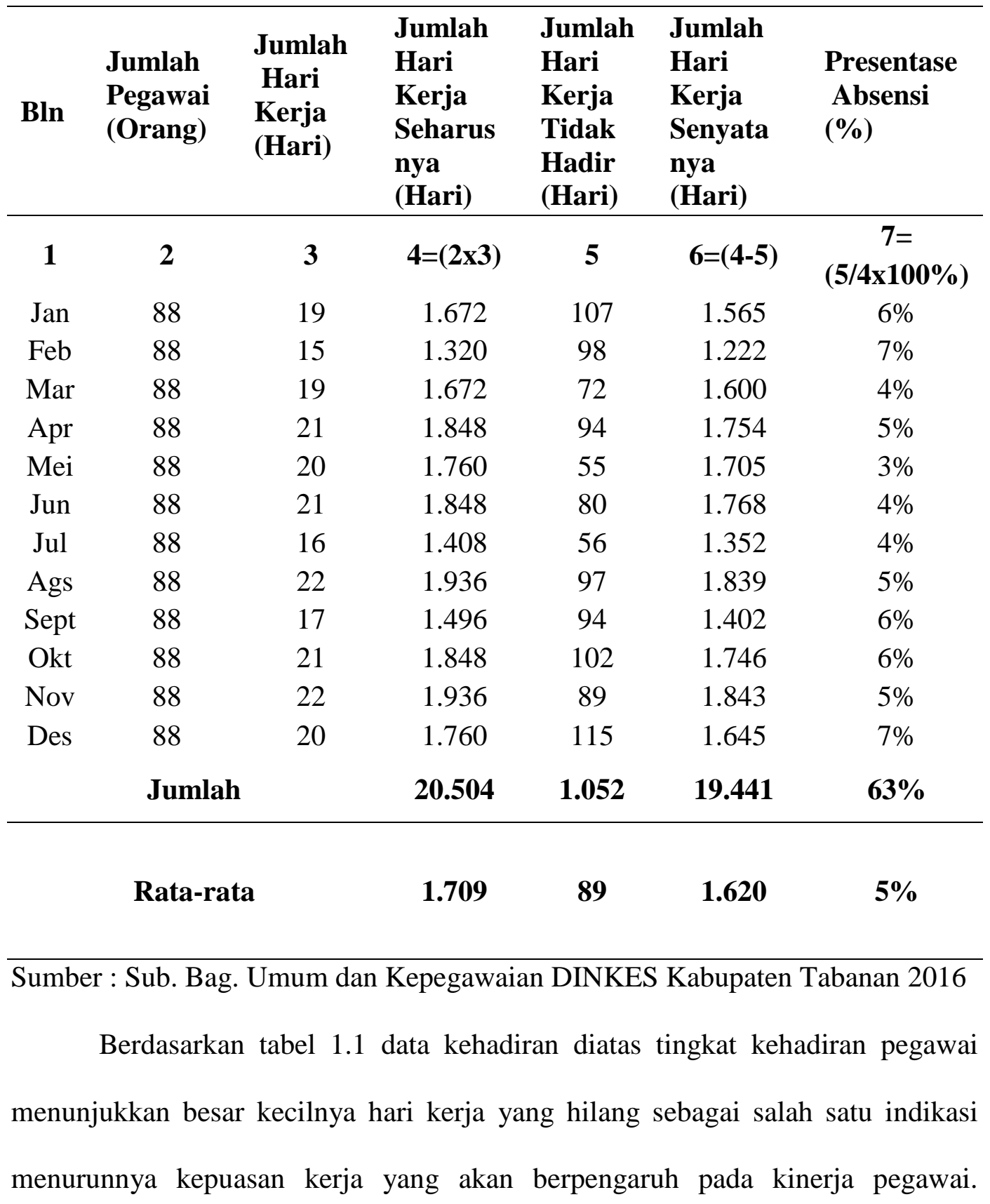


Menurut Mudiarta, dkk (2007:93), bahwa tingkat absen yang wajar berada di bawah 3\%, diatas 3\% sampai 10\% dianggap tinggi. Pada Dinkes Tabanan menunjukan tingkat absen sebesar 5\% yang disebabkan oleh disiplin kerja pegawai yang rendah. Adanya permasalahan berkaitan dengan budaya organisai dan komunikasi internal meningkatkan kinerja yang di mediasi oleh kepuasan kerja pegawai pada Dinas Kesehatan Kabupaten Tabanan di Tabanan maka sangat layak untuk diteliti.

Penelitian ini bertujuan untuk mengetahui pengaruh budaya organisasi, komunikasi internal terhadap kepuasan kerja dan kinerja pegawai pada Dinas Kesehatan Kabupaten Tabanan.

Menurut Robbins (2006:721), Budaya organisasi mengacu kesistem makna bersama yang di anut oleh anggota-anggota yang membedakan organisasi itu dari organisasi yang lain. Sistem makna bersama ini bila diamati dengan lebih seksama, merupakan seperangkat karakteristik utama yang dihargai oleh organisasi itu.

Kata komunikasi berasal dari bahasa Latin comunis, yang berarti membuat kebersamaan atau membangun kebersamaan antara dua orang atau lebih. Filippo dalam Mangkunegara (2008:145) menyatakan communication is the act of inducing others to interpret an idea in the manner intended by speaker or writer (komunikasi adalah aktivitas yang menyebabkan orang lain menginterpretasikan suatu ide, terutama yang dimaksudkan oleh pembicara atau penulis). Menurut Effendy (2009:129) komunikasi eksternal terdiri atas dua jalur secara timbal balik, yakni komunikasi dari organisasi kepada khalayak dan dari khalayak kepada 
organisasi. Komunikasi kepada khalayak pada umumnya bersifat informatif, yang dilakukan sedemikian rupa sehingga khalayak merasa memiliki keterlibatan, setidak-tidaknya ada hubungan batin. Komunikasi dari khalayak kepada orgnisasi merupakan umpan balik sebagai efek dari kegiatan komunikasi yang dilakukan oleh organisasi.

Usman (2010:498) berpendapat bahwa kepuasan kerja adalah sikap seseorang terhadap pekerjaannya yang mencerminkan pengalaman yang menyenangkan dan tidak menyenangkan dalam pekerjaannya serta harapanharapannya terdapat pengalaman masa depan. Menurut Rivai (2012:246), kepuasan kerja adalah penilaian dari pekerja tentang seberapa jauh pekerjaannya secara keseluruhan memuaskan kebutuhannya.

Kinerja adalah hasil kerja secara kualitas dan kuantitas yang dicapai oleh seorang pegawai dalam melaksanakan tugasnya sesuai dengan tanggung jawab yang diberikan kepadanya, menurut Mangkunegara (2009:67). Menurut Sedarmayanti (2011:260), kinerja merupakan terjemahan dari performance yang berarti hasil kerja seorang pekerja, sebuah proses manajemen atau suatu organisasi secara keseluruhan, dimana hasil kerja tersebut harus dapat ditunjukkan buktinya secara konkrit dan dapat diukur (dibandingkan dengan standar yang telah ditentukan).

Penelitian yang dilakukan oleh Chaterina (2012) menyatakan bahwa budaya organisasi berpengaruh positif dan signifikan terhadap kepuasan kerja pegawai. Penelitian Krik L.Rongga (2001) menyatakan bahwa budaya organisasi dapat meningkatkan kepuasan kerja pegawai. Selain itu, budaya organisasi juga 
memiliki hubungan dengan kinerja melalui kepuasan kerja pegawai, dimana budaya organisasi tidak lepas dari strategi organisasi, termasuk visi dan misi organisasi itu sendiri dan merupakan salah satu faktor penting dalam implementasi strategi untuk peningkatan kinerja dalam organisasi.

Hubungan komunikasi internal dengan kepuasan kerja pegawai yakni komunikasi internal secara positif berpengaruh terhadap kepuasan kerja pegawai. Hal ini didukung oleh penelitian Nurani (2014), menyatakan bahwa komunikasi intenal mempunyai pengaruh positif dan signifikan terhadap kepuasan kerja. Berdasarkan atas kajian teori dan kajian empiris yang telah disampaikan maka dapat dirumuskan hipotesis sebagai berikut :

H1 Budaya organisasi berpengaruh positif dan signifikan terhadap kepuasan kerja pegawai.

H2 Komunikasi internal berpengaruh positif dan signifikan terhadap kepuasan kerja pegawai.

Dewi herlina (2013) menyimpulkan hasil penelitiannya, bahwa budaya organisasi berpengaruh positif dan signifikan terhadap kinerja karyawan yang berarti bahwa budaya organisasi dengan kinerja pegawai adalah hubungan bernilai positif. Pada budaya organisasi terhadap hubungan yang terjadi dengan kinerja, dimana budaya organisasi mengacu pada system makna yang dianut oleh anggotaanggota organisasi yang membedakan organisasi tersebut dengan organisasi yang lain. Hal ini didukung dengan penelitian yang dilakukan oleh Rivai (2004), menyatakan bahwa budaya organisasi yang semakin baik akan membuat kinerja pegawai semakin tinggi begitu pula sebaliknya. 
Komunikasi internal terhadap kinerja, yakni komunikasi yang efektif di dalam suatu organiasi akan mendorong motivasi dan timbulnya kinerja. Hal ini di dukung juga oleh penelitian empirik Masithoh (2008), dalam penelitiannya yang menunjukkan hasil bahwa komunikasi internal berpengaruh positif dan signifikasn terhadap kinerja. Berdasarkan atas kajian teori dan kajian empiris yang telah disampaikan maka dapat dirumuskan hipotesis sebagai berikut :

H3 Budaya organisasi berpengaruh positif dan signifikan terhadap kinerja pegawai

H4 Komunikasi internal berpengaruh positif dan signifikan terhadap kinerja pegawai

Hubungan kepuasan kerja pegawai dengan kinerja pegawai dimana kepuasan kerja terhadap kinerja terdapat pengaruh yang signifikan dan positif (Nurtjahjani dan Masreviastuti, 2007). Hasil penelitian ini sesuai dengan pendapat dan teori yang diungkap oleh Donnely, dkk, (1994) yang menjelaskan bahwa kepuasan kerja pegawai menyebabkan adanya peningkatan atau penurunan kinerja, pekerja yang puas akan lebih produktif dibandingkan dengan pekerja yang tidak puas. Hal yang paling mendasar adalah pengaruh kepuasan kerja pegawai terhadap organiasi yang akan mempengaruhi kinerja. Dengan demikian dapat disimpulkan bahwa pengaruh kepuasan kerja pegawai terhadap kinerja adalah tinggi rendahnya tingkat kepuasan kerja pegawai yang dirasakan akan mempengaruhi kinerja. Apabila kepuasan kerja pegawai tercapai maka kinerja atas organisasi tinggi. Hipotesis penelitian ini adalah:

H5 Kepuasan kerja pegawai berpengaruh positif dan signifikan terhadap kinerja pegawai. 


\section{METODE PENELITIAN}

Dalam penelitian ini dilakukan observasi, wawancara, dokumentasi, kepustakaan dan kuisioner dengan mengunakan instrument yang telah disusun untuk mengumpulkan data. Populasi dalam penelitian ini adalah pegawai pada Dinas Kesehatan Kabupaten Tabanan di Tabanan tahun 2016 sebanyak 88 orang, berhubung populasinya 88 maka besarnya sampel ditentukan $100 \%$ hingga sampel yang dipakai adalah 88 orang (sampling jenuh). Data yang diperoleh kemudian diuji validitas dan reliabilitas dan selanjutnya dilakukan analisis jalur (Path Analysis). Untuk menguji kekuatan pengaruh tidak langsung variabel independen (X1 dan X2) ke variabel dependen (Y2) melalui variabel Mediasi (Y1).

\section{HASIL PENELITIAN DAN PEMBAHASAN}

\section{Karakteristik Responden}

Dari tabel 1 dapat dilihat bahwa pegawai Dinas Kesehatan Kabupaten Tabanan sebanyak 88 orang didominasi oleh responden perempuan sebanyak 48 orang atau 54,5\% dan ditinjau dari tingkat pendidikan jumlah terbanyak adalah responden dengan tingkat pendidikan Sarjana (S1) yaitu dengan41 orang atau 46,6 $\%$ sedangkan apabila ditinjau dari segi umur responden jumlah terbanyak ada pada responden dengan umur 41 tahun s/d 50 tahun dengan jumlah 32 orang atau $36,4 \%$. 
Tabel 1. Karakteristik Responden

\begin{tabular}{cccc}
\hline $\mathbf{1}$ & Jenis Kelamin & Jumlah (Orang) & Persentase (\%) \\
\hline & Laki-Laki & 40 & 45,5 \\
& Perempuan & 48 & 54,5 \\
Total & $\mathbf{8 8}$ & $\mathbf{1 0 0}$ \\
\hline $\mathbf{2}$ & Pendidikan & & \\
\hline & SMA/SMK & 7 & 8,0 \\
Diploma & 29 & 33,0 \\
S1 & 41 & 46,6 \\
& S2/S3 & 11 & 12,5 \\
& Total & $\mathbf{8 8}$ & $\mathbf{1 0 0}$ \\
\hline $\mathbf{3}$ & Umur (Tahun) & & 8,0 \\
& $21-30$ & 7 & 30,7 \\
& $31-40$ & 27 & 36,4 \\
& $41-50$ & 32 & 25,0 \\
& $>50$ & 22 & $\mathbf{1 0 0}$ \\
\hline
\end{tabular}

Sumber : Data Diolah

\section{Deskripsi Variabel}

Variabel budaya organisasi (X1) mempunyai nilai minimum 16 dan nilai maksimum 40. Mean sebesar 28,01. Standar deviasinya 7,43, hal ini berarti terjadi penyimpangan budaya organisasi terhadap nilai rata-ratanya sebesar 7,43.

Variabel komunikasi internal (X2) mempunyai nilai minimum 20 dan nilai maksimum 50. Mean sebesar 36,88. Standar deviasinya 7,27, hal ini berarti terjadi penyimpangan komunikasi internal terhadap nilai rata-ratanya sebesar 7,27.

Variabel kepuasan kerja (Y1)mempunyai nilai minimum 9 dan nilai maksimum 23. Mean sebesar 16,72. Standar deviasinya 3,56, hal ini berarti terjadi penyimpangan komunikasi internal terhadap nilai rata-ratanya sebesar 3,56

Variabel kinerja pegawai (Y2) mempunyai nilai minimum 8 dan nilai maksimum 20. Mean sebesar 15,0. Standar deviasinya 3,05, hal ini berarti terjadi penyimpangan komunikasi internal terhadap nilai rata-ratanya sebesar 3,05. 


\section{Analisis jalur (Path Analysis)}

Analisi data yang digunakan untuk membahas permasalahan dalam penelitian ini adalah tehnik analisis jalur (path analysis). Model analisis jalur digunakan untuk menganalisis pola hubungan antar variable dengan tujuan untuk mengetahui pengaruh langsung seperangkat variable bebas (eksogen) terhadap variable terikat (endogen).

Sebelum dilakukan analisis hubungan antar variable dan pengujian hipotesis terlebih dahulu dilakukan validasi model dengan memperhatikan nilai $R$ Square pada Model Summary.

Tabel 2. Coefficients Substruktur 1 (Model 1)

Coefficients

\begin{tabular}{|ll|r|r|r|r|r|}
\hline \multirow{2}{*}{ Model } & \multicolumn{2}{|c|}{$\begin{array}{c}\text { Unstandardized } \\
\text { Coefficients }\end{array}$} & \multicolumn{2}{c|}{$\begin{array}{c}\text { Standardized } \\
\text { Coefficients }\end{array}$} & \\
\cline { 3 - 5 } & & \multicolumn{1}{|c|}{ B } & Std. Error & \multicolumn{1}{c|}{ Beta } & \multicolumn{1}{c|}{ Sig. } \\
\hline 1 & (Constant) &,- 052 &, 166 & &,- 312 &, 756 \\
& Budaya organisasi &, 206 &, 008 &, 431 & 26,731 &, 000 \\
& Komunikasi internal &, 298 &, 008 &, 608 & 37,759 &, 000 \\
\hline
\end{tabular}

a. Dependent Variable: Kepuasan kerja

Tabel 3. Coefficients Substruktur 2 (Model 2)

Coefficients ${ }^{\mathrm{a}}$

\begin{tabular}{|ll|r|r|r|r|r|}
\hline \multirow{2}{*}{ Model } & \multicolumn{2}{|c|}{$\begin{array}{c}\text { Unstandardized } \\
\text { Coefficients }\end{array}$} & \multicolumn{2}{c|}{$\begin{array}{c}\text { Standardized } \\
\text { Coefficients }\end{array}$} & \\
\cline { 3 - 5 } & & \multicolumn{1}{|c|}{ B } & Std. Error & \multicolumn{1}{|c|}{ Beta } & \multicolumn{1}{c|}{ t } & \multicolumn{1}{c|}{ Sig. } \\
\hline 1 & (Constant) &,- 384 &, 163 & & $-2,358$ &, 021 \\
& Budaya organisasi &, 390 &, 023 &, 369 & 16,760 &, 000 \\
& Komunikasi internal &, 561 &, 033 &, 519 & 17,141 &, 000 \\
& Kepuasan kerja &, 327 &, 107 &, 148 & 3,068 &, 003 \\
\hline
\end{tabular}

a. Dependent Variable: Kinerja

Berdasarkan perhitungan terhadap substruktur 1, dan 2, maka dapat diketahui besarnya pengaruh langsung, pengaruh tidak langsung dan pengaruh total antar variabel. Perhitungan pengaruh antar variabel adalah sebagai berikut. 
Tabel 4. Pengaruh Langsung, Pengaruh Tidak Langsung dan Pengaruh Total

\begin{tabular}{|c|c|c|c|c|c|}
\hline & \multicolumn{2}{|c|}{ Variabel } & $\begin{array}{l}\text { Pengaruh } \\
\text { langsung }\end{array}$ & $\begin{array}{c}\text { Pengaruh } \\
\text { Tidak langsung } \\
\text { Melalui } \\
\text { kepuasan kerja }\end{array}$ & $\begin{array}{c}\text { Pengaruh } \\
\text { Total }\end{array}$ \\
\hline $\begin{array}{l}\text { Budaya } \\
\text { organisasi }\end{array}$ & $\rightarrow$ & Kepuasan kerja & 0,431 & - & 0,431 \\
\hline $\begin{array}{l}\text { Komunikasi } \\
\text { internal } \\
\text { Kepuasan }\end{array}$ & $\rightarrow$ & Kepuasan kerja & 0,608 & - & 0,608 \\
\hline kerja & $\rightarrow$ & Kinerja & 0,148 & - & 0,148 \\
\hline $\begin{array}{l}\text { Budya } \\
\text { organisasi } \\
\text { Komunikasi } \\
\text { internal }\end{array}$ & & Kinerja & 0,369 & 0,06 & 0,429 \\
\hline
\end{tabular}

Sumber : Data diolah 2017

\section{Pengaruh Budaya Organisasi Terhadap Kepuasan kerja}

Berdasarkan hasil uji emperik diperoleh taraf signifikansi penelitian variabel budaya organisasi terhadap kepuasan kerja sebesar $0,000<0,05$, sehingga $\mathrm{H} 0$ ditolak dan $\mathrm{H} 1$ diterima, dengan kata lain budaya organisasi berpengaruh positif dan signifikan terhadap kepuasan kerja pegawai pada Dinkes Kabupaten Tabanan.

\section{Pengaruh Komunikasi Internal Terhadap Kepuasan kerja}

Berdasarkan hasil uji emperik diperoleh taraf signifikansi penelitian variabel komunikasi internal terhadap kepuasan kerja sebesar $0,000<0,05$, sehingga H0 ditolak dan $\mathrm{H} 2$ diterima, dengan kata lain komunikasi internal berpengaruh positif dan signifikan terhadap kepuasan kerja pegawai pada Dinkes Kabupaten Tabanan.

\section{Pengaruh Budaya Organisasi Terhadap Kinerja}

Berdasarkan hasil uji emperik diperoleh taraf signifikansi penelitian untuk variabel budya organisasi terhadap kinerja sebesar $0,000<0,05$, sehingga H0 
ditolak dan H3 diterima, dengan kata lain budaya organisasi berpengaruh signifikan terhadap kinerja pegawai pada Dinkes Kabupaten Tabanan.

\section{Pengaruh Komunikasi internal Terhadap Kinerja}

Berdasarkan hasil uji emperik diperoleh taraf signifikansi penelitian untuk variabel komunikasi internal terhadap kepuasan kerja sebesar $0,000<0,05$, sehingga H0 ditolak dan H4 diterima, dengan kata lain komunikasi internal berpengaruh positif dan signifikan terhadap kinerja pegawai pada Dinkes Kabupaten Tabanan.

\section{Pengaruh Kepuasan Kerja Terhadap Kinerja}

Berdasarkan hasil uji emperik diperoleh taraf signifikansi penelitian untuk variabel kepuasan kerja terhadap kinerja sebesar $0,000<0,05$, sehingga H0 ditolak dan H5 diterima, dengan kata lain kepuasan kerja berpengaruh positif dan signifikan terhadap kinerja pegawai pada Dinkes Kabupaten Tabanan.

\section{Pengaruh Budaya Organisasi Terhadap Kinerja Dengan Kepuasan Kerja Sebagai Variabel Mediasi}

Berdasarkan hasil uji emperik diperoleh taraf signifikansi penelitian untuk variabel budaya organisasi terhadap kinerja dengan nilai $Z$ 3,03 > 1,96, sehingga H0 ditolak dan H6 diterima, dengan kata lain budaya organisasi berpengaruh positif dan signifikan terhadap kinerja pegawai melalui kepuasan kerja pada Dinkes Kabupaten Tabanan.

Pengaruh Komunikasi Internal Terhadap Kinerja Dengan Kepuasan Kerja Sebagai Variabel Mediasi

Berdasarkan hasil uji emperik diperoleh taraf signifikansi penelitian untuk 
variabel komunikasi internal terhadap kinerja dengan nilai Z 3,044>1,96, sehingga H0 ditolak dan H7 diterima, dengan kata lain komunikasi internal berpengaruh positif dan signifikan terhadap kinerja pegawai melalui kepuasan kerja pada Dinkes Kabupaten Tabanan.

\section{SIMPULAN}

Berdasarkan hasil pembahasan, maka dapat disimpulkan bahwa budaya organisasi berpengaruh positif dan signifikan terhadap kepuasan kerja, komunikasi internal berpengaruh positif dan signifikan terhadap kepuasan kerja, budaya organisasi berpengaruh positif dan signifikan terhadap kinerja, komunikasi internal berpengaruh positif dan signifikan terhadap kinerja, kepuasan kerja berpengaruh positif dan signifikan terhadap kinerja, budaya organisasi berpengaruh positif dan signifikan terhadap kinerja, dan komunikasi internal berpengaruh positif dan signifikan terhadap kinerja

Saran-saran yang dapat diberikan berdasarkan hasil penelitian ini adalah memperhatikan interaksi bagi setiap pegawai agar terciptanya hubungan yang harmonis, baik di lingkungan kerja maupun diluar lingkungan kerja, perlu secara rutin menanamkan dan mensosialisasikan budaya organisasi sehingga dapat diaplikasikan dan diterapkan secara konsisten oleh seluruh pegawai, sharing antara pimpinan dan seluruh pegawai, agar terciptanya hubungan antara pimpinan dan bawahan, perlu adanya peningkatan pada dimensi pertimbangan individual, dimana pemimpin diharapkan dapat mengarah pada pemahaman dan perhatian pada potensi dan kemampuan yang dimiliki bawahannya, pemimpin harus memandang setiap bawahanya sebagai aset organisasi, sehingga memudahkan 
membina dan mengarahkan potensi serta kemampuan bawahannya, harus memperbaiki sistem pemberian tunjangan uang makan bagi pegawai agar pegawai termotivasi lebih meningkatkan kepuasan kerja, yang dapat mempengaruhi kinerja di masa yang akan dating, pimpinan perlu sesekali mengajak seluruh pegawainya dengan melakukan pejalanan ke tempat yang dapat melepaskan sejenak beban dan pikiran pegawai.

\section{DAFTAR PUSTAKA}

Effendy, Onong Uchjana. 2009. Komunikasi Teori dan Praktek. Bandung: PT.Reamaja Rosdakarya.

Harlina, Dewi. Syafrizal Chan. Yuhelmi. 2013. Pengaruh Budaya Organisasi Dan Lingkungan Kerja Terhadap Kinerja Pegawai STAIN Kerici Dengan Kepuasan Kerja Sebagai Variabel Intervening. Program Magister Sains Manajemen Program Pascasarjana. 3(2): 1-14.

Kretner \& Kinicki. 2005. Perilaku Organisasi. Jakarta: Salemba Empat.

Ghozali, Imam. 2013. Aplikasi Analisis Multivariat dengan Program IBM SPSS 2 Edisi 7. Semarang: Penerbit Universitas Diponegoro.

Mangkunegara, AA. Anwar Prabu. (2009). Manajemen Sumber Daya Manusia Perusahaan. Bandung:Rosda

Rivai, Veithzal Deddy Mulyadi. 2012. Kepemimpinan Dan Perilaku Organisasi Edisi Ketiga. Jakarta: PT. Raja Grafindo Persada.

Robbins, Stephen P.Timothy A. Judge. 2008. Perilaku Organisasi Buku 2. Jakarta:Salemba Empat.

Sugiyono, 2014. Metode Penelitian Manajemen. Bandung:Alfabeta.

Udayanto, Rahmat Restu. I Wayan Bagia. Ni Nyoman Yulianthini. 2015. Pengaruh Komunikasi Internal Dan Disiplin Kerja Terhadap Kinerja Karyawan PT.Coca Cola. Bisma Universitas Pendidikan Ganesha Jurusan Manajemen. 3.

Wibowo. 2011. Manajemen Kinerja. Jakarta: PT.Raja Grafindo Persada. 